\title{
Challenges in the Development of China's Cultural Trade and Countermeasures Analysis
}

\author{
Chunyan Chen \\ Shaanxi Normal University-International Business School \\ Xi'an Shannxi \\ Chenchunyan916@163.com
}

\begin{abstract}
Cultural trade has gradually become one of the key areas of today's international trade competition and is the main direction of a country's trade transformation and upgrading. With the expansion of the absolute scale of Chinese cultural trade, China has become a veritable large-scale cultural trade country. However, there is still a certain distance from the strength of cultural trade. Based on this background, it is of great significance to study how our country can enhance the competitiveness of our country's cultural trade and achieve the e status of a strong country in culture trade. This article first introduced the current status of Chinese cultural trade. Then through the analysis of international competitiveness, it is found that the international competitiveness of China's cultural industry is very weak. Then it analyzes some problems existing in China's cultural trade, and finally puts forward corresponding solutions.
\end{abstract}

Keywords-Cultural trade; International competitiveness; Cultural trade problems; Countermeasures

\section{INTRODUCTION}

In the contemporary international market, the status and role of cultural trade in contemporary state-to-state trade has become more and more prominent, becoming an important symbol of comprehensive national power, and the competition among countries for cultural trade has become increasingly fierce. This cultural "dumping" is more aggressive than the dumping of commodities. It will not only affect the development of China's cultural industry, it will also have an impact on our country's traditional culture, and it will have a subtle impact on China's national values and modes of thinking China is still a developing country [1]. To achieve a corner overtaking, we must find a new growth point. Cultural trade can be our new growth point. Cultural trade can be our new growth point. At present, China's cultural industry is at a disadvantage in the international market. Therefore, in order to realize the great rejuvenation of the Chinese nation, we must attach importance to the cultural industry. We must take the cultural industry to drive China's economic development and help improve China's overall national strength.

\section{DeVelopment Status of ChinA's Cultural Trade}

A. Overall trade surplus of goods, serious deficit in cultural trade

TABLE I. CHINA'S CULTURAL PRODUCT TRADE STATISTICS FOR 2015

\begin{tabular}{|c|c|c|c|c|}
\hline & $\begin{array}{c}\text { Number of exports } \\
\text { (parts, hours) }\end{array}$ & $\begin{array}{c}\text { Export amount (ten } \\
\text { thousand US } \\
\text { dollars) }\end{array}$ & $\begin{array}{c}\text { Number of imports } \\
\text { (share, hour) }\end{array}$ & $\begin{array}{c}\text { Import amount (ten } \\
\text { thousand US dollars) }\end{array}$ \\
\hline books & 1278.7 & 5221.67 & 1418.78 & 14499.25 \\
\hline Periodical & 240.35 & 461.64 & 357.66 & 14323.10 \\
\hline newspaper & 33.53 & 43.43 & 1035.31 & 99.54 \\
\hline Recording total & 5403 & 7.53 & 7547 & 9.19 \\
\hline Total video & 3722 & 2.36 & & \\
\hline Electronic & 284 & 14.77 & & \\
\hline
\end{tabular}




\begin{tabular}{|c|c|c|c|c|}
\hline \multicolumn{3}{|c|}{ Table I, cont } \\
\hline Digital publication & & 112.1 & & 24098.84 \\
\hline TV show & 25352 & 8100.18 & 31109 时 & 15684.85 \\
\hline total & & 13963.68 & & 70449.95 \\
\hline
\end{tabular}

a. Data Sources: According to the 2015 Statistical Yearbook of the National Bureau of Statistics and the 2015 annual data

During the period from 2011 to 2015 , China's trade import and export volume as a whole showed an upward trend. China's goods trade situation is very good. There is a trade surplus in the trade of goods, and the trade surplus is expanding, and the trade in goods is in a dominant position. In contrast, from the data obtained in Table 1, China's cultural trade is in a weak position. From the table, we can clearly see that books, periodicals, newspapers, audio-visual products, electronic publications, and television programs in China are at a disadvantage in international trade. Status is inconsistent with the situation of China's goods trade, and the cultural trade deficit is serious. China is a big trading country, but it is only an importing country in terms of cultural trade. The huge import volume of cultural products, the small amount of exports, and the serious trade deficits, especially in the audiovideo and electronic publications markets, have caused a serious and growing trade deficit, and the trade situation has been deteriorating. China's cultural trade is in a weak position. China has not effectively spread and protect China's culture through cultural trade, reflecting that local culture's ability to withstand shocks is very weak [2].

\section{B. Cultural trade product structure is unbalanced and its added value is not high}

Cultural products can be divided into cultural hardware products and cultural software products. Hardware products are those tools and carriers that carry cultural content. China's cultural hardware has a trade surplus. Cultural software products, including movies, TV series, animation and novels, video tapes, periodicals, newspapers, etc., are mainly in the field of software trade, and the field of cultural software products is weak. In this sense, China's cultural trade is characterized by "strong hardware and weak software [3]."

\section{The cultural trade area is too concentrated}

There are many countries and regions that have cultural trade with China. However, it is too concentrated in the import and export areas of Chinese cultural products. Regardless of whether it is exported or imported, the main countries and regions for cultural trade are concentrated in the United States, Japan, HongKong, South Korea, Singapore, and European countries [5]. The import and export of cultural trade is concentrated, and the structure of trade countries is unbalanced, which intuitively reflects the low degree of internationalization of China's cultural industry. The concentration of the introduction land reflects that the cultural industries in the western developed countries led by the United States are relatively developed. At the same time, Singapore, Japan, and South Korea are very close to China's cultural trade, reflecting that the culture of the same system can resonate with each other [6].

\section{ANAlysis OF ChinA's CUltural TRADE COMPETITIVENESS}

NTB (Normalized Trade Balance) It is the ratio of the net export value of a certain product to the total import and export volume, and it is a relative indicator commonly used to measure international competitiveness [7].

The specific formula is :

$$
\text { NTB }=(\text { Xij-Mij }) /(X i j+M i j)
$$

Among them, $\mathrm{Xij}$ is the total amount of $\mathrm{j}$ product exports in country $\mathrm{i}$ or region, and $\mathrm{Mij}$ is the total amount of $\mathrm{j}$ product imports in country $i$ or region. The NTB range is $(-1,1)$. If the NTB index is $>0$, then it is competitive. If not, it is not competitive. Its size is directly proportional to the level of competitiveness.

TABLE II. COMPETITIVE ANALYSIS OF MaJor CULtural Products

\begin{tabular}{lccccc}
\hline years & $\begin{array}{c}\text { Export amount } \\
(\text { US\$10,000) }\end{array}$ & $\begin{array}{c}\text { Import amount } \\
\text { (US\$10,000) }\end{array}$ & $\begin{array}{c}\text { Net exports } \\
(\text { US } \$ 10,000)\end{array}$ & $\begin{array}{c}\text { Total import } \\
\text { and export } \\
(\text { US\$10,000) }\end{array}$ & NTB index \\
\hline 2011 & 3940.68 & 42508.04 & -38567.36 & 46448.72 & -0.83 \\
2012 & 9474.08 & 46807.6 & -37333.52 & 56281.68 & -0.66 \\
2013 & 6134.83 & 48070.97 & -41936.14 & 54205.8 & -0.77 \\
2014 & 5806.12 & 49381.7 & -43575.58 & 55187.82 & -0.79 \\
2015 & 5863.5 & 54765.2 & -48901.7 & 60628.7 & -0.81 \\
\hline
\end{tabular}


From the analysis of the trade competitiveness index, from 2011 to 2015, the NTB index of China's cultural products has always been less than -0.5 . The above table can be used to derive the competitiveness of China's cultural products, and it is in a poor competitive range from 2012 to 2014. The situation was even worse in 2011 and 2015, which exposed the shortcomings of China's cultural products in terms of international trade competitiveness. This situation reminds us that we need to shift our focus to China's cultural trade, appropriately promote the development of cultural trade, It is necessary to give play to the government's policy role, bring cultural trade development to the correct development path, enhance the international competitiveness of China's cultural products, improve China's foreign cultural trade structure as much as possible, and promote the development of cultural trade.

\section{Challenges in the Development of China's Cultural} TRADE

\section{A. Cultural industry laws and regulations are not perfect}

In the past two decades, the rapidly development of cultural trade in Japan and South Korea has been supported by the state system. Since the end of the last century, Japan has put forward three major strategies to support the development of cultural industries. They are the strategy of building a nation through culture, the strategy of establishing a country based on intellectual property rights, and the strategy of building a country through tourism. In addition, Japan has also promulgated a series of laws and regulations, of which the "Copyright Management Law" is more representative and gives some guidance to the cultural industry. In recent years, according to the actual situation, Japan has successively promulgated several laws to regulate Cultural market. The introduction of laws and regulations on cultural trade in China was relatively late, and there were fewer laws and regulations in China's cultural market, and the protection of related rights and interests was low, and the related penalties were also limited. The legitimate rights and interests of many cultural enterprises have not been adequately safeguarded, and they have lost many benefits [8].

\section{B. Impact of Foreign Cultural Industry on China's Cultural Industry}

China's cultural industry is still unable to compete with developed countries. There is a large gap in capital, management, marketing, and innovation. It is at a disadvantage in international trade. Many aspects of China's cultural industry are severely affected by foreign cultural industries. In terms of movies, the total box office in 2016 was 45.712 billion yuan, a total of 450 films were released, of which 92 were imported films, and the final box office accounted for $48 \%$. As China's opening up to the outside world is further deepened, the opening of the mainland market in China will inevitably make China's cultural market inevitably subject to a strong invasion and infiltration of foreign cultures. The pressure for competition is great.

\section{The use of the relevant industry is not obvious}

The cultural industry influences the overall economy by adding cultural value to other industries and interacting with other industries. It is the role of the cultural industry in associating other industries. In contrast, domestic TV dramas exported to South Korea only output TV copyrights, without driving the development of a series of related industries.

\section{Lack of cultural trade talents}

China's cultural industry has not caused much repercussions in the international market. One of the important points is that our country lacks specialized talents specialized in cultural trade and displays outstanding cultural products created by our country to other countries and regions. At present, there are many people engaged in foreign trade in China, but due to the relatively high requirements for talents in the trade of cultural products, talents specialized in cultural trade have been in short supply.

\section{E. The existence of cultural discounts}

"Cultural discounts" are trade barriers caused by the country's cultural trade due to its different cultural background and low national acceptance. The existence of "cultural discounts" will make it easier for China to export cultural products to countries with similar cultures than countries with very different cultures. China's major cultural and trading partners may turn to countries with the same cultural background, which is detrimental to the global culture of our country. Balanced development.

\section{China's Cultural Trade DeVElopment COUNTERMEASURES}

\section{A. Improve the corresponding laws and regulations of the cultural market to protect legitimate rights and interests}

China should first abide by the norms concerning the global nature of cultural trade, and secondly, establish a sound intellectual property system, strive to be in line with the international intellectual property system, and formulate corresponding policies based on actual problems. Secondly, laws and regulations must be thoroughly implemented and implemented. Cultural enterprises should raise their legal awareness and know how to use legal means to protect their legitimate rights and interests from infringement. If conditions permit, special departments can be set up to carry out legal rights protection activities [9].

\section{B. Appropriate Trade Protection Policy}

In this world advocating free trade, China is also actively advocating the weakening of tariffs, promoting free trade between countries, and playing the unwritten rule of "cultural exceptions" in the field of cultural trade. The principle of "cultural exceptions" provides a theoretical basis for China's implementation of appropriate cultural trade protection policies. Cultural industry trade needs gradual liberalization. At present, China should adopt appropriate trade protectionism, restrict it in a targeted manner, and trade protection for films, animation and other industries. The methods that the government can 
adopt include fiscal subsidies, export tax rebates, and credit support.

\section{Pulling the Development of Related Industries}

It is necessary to give full play to the role of the cultural industry. Promote the construction of cultural brands, and combine cultural elements with tourism elements to make the cultural industry play a leading role in stimulating the development of tourism. Intensify the development of cultural product derivatives, and carry out in-depth development of core cultural products and develop some derivatives with higher value.

\section{Strengthening Professional Talents in Cultural Trade}

For domestic self-cultivation of cultural and trade talents, we will actively cultivate specialized talents who can directly engage in international cultural trade and enrich China's talent pool. While cultivating outstanding talents at home, they have also introduced high-end talent from abroad and left behind talented people. They have gradually improved their advantages in cultural trade talents. In addition, many people in mainland China have come to study abroad, and the return of study abroad can also bring advanced management experience and mature business models to China's cultural trade industry. The cultivation of talents cannot be accomplished overnight. This is a work that needs long-term adherence. While cultivating outstanding talents, we have also introduced highend talent from abroad to advance our country's cultural and trade talents gradually.

\section{E. Seeking common ground while reducing "cultural discounts"}

In order to reduce "cultural discounts", Chinese cultural enterprises must understand local customs when conducting foreign trade. Different cultural products must be developed for different countries and regions in order to satisfy the local people to the maximum extent possible. On this basis, the cultural products should be upgraded so that they can cross cultural barriers and be accepted by consumers in different cultural environments. Finally, cultural enterprises can use the international platforms such as international art festivals and world expo to make China the cultural trade condition is better [10].

\section{CONCLUSION}

If China's cultural trade wants to be competitive in the international cultural trade market, we must vigorously develop China's cultural industry, nurture outstanding cultural enterprises, and enhance the international competitiveness of China's cultural trade. At present, China's cultural trade has problems of one kind or another. We need to specifically analyze the specific problems of the issues and propose corresponding countermeasures to solve the problems. Through the analysis of the full text, China's cultural trade is temporarily at a disadvantage, and there is a big gap with developed countries, China's cultural industry trade has great potential for development and development space is large enough. China now has enough funds to support the development of cultural trade. In addition, Chinese traditional culture has a long history. The resources available to our posterity by our predecessors are very large. Therefore, our country's cultural and trade development has a bright future. With the efforts of Chinese, we will certainly be invincible in the international market.

\section{REFERENCES}

[1] Yuying Zhang. China's Cultural Product Trade Deficit and Coping Strategies [J]. Journal of Liaoning Normal University, 2015, 38(1): 49 53. (In Chinese)

[2] Yang Lliu, Ruxiao Qu, Yanping Zeng. What are the key factors affecting the trade of cultural products - - Evidence from OECD countries[J].International Trade Issues,2013,11(2):72 81. (In Chinese)

[3] Yuhan Guo.Analysis of the Influence of Cultural Distance on China's Core Cultural Products Export Trade[D]. Master's Thesis. Jinan: Shandong University, 2015. (In Chinese)

[4] Yaya Li. Research on the Competitiveness of China's Cultural Trade[D]. Master's Thesis. Beijing: Capital University of Economics and Business, 2013. (In Chinese)

[5] Xingyun Ma. Research on International Competitiveness of Chinese Cultural Trade[D]. Master's Thesis. Jinan: Shandong University of Finance and Economics, 2014. (In Chinese)

[6] Qiuyuan Qu. Research on the Influence of Industrial Opening on the International Competitiveness of China's Cultural Industry [D]. Master's Thesis. Changsha: Hunan University, 2014. (In Chinese)

[7] Xuan Zhao. Research on American Cultural Export Strategy in the Age of Globalization [D]. Doctoral Dissertation. Changchun: Jilin University, 2014. (In Chinese)

[8] Ying Wang, Jianjun Huang. The Problems Existing in China's Current Cultural Trade Policy and Adjustment Countermeasures[J].International Trade, 2016,1(4):64 67. (In Chinese)

[9] Xiaopeng Liu.On the Influence of Cultural Trade Barriers on China's Cultural Trade [J]. Commercial Economic Research, 2013, 23:55 56. (In Chinese)

[10] ChunLiang Chen, Yi-Long Jaw. Building Global Gynamic Capabilities through Innovation: A Case Study of Taiwan's Cultural Organizations [J]. Journal of Engineering and Technology Management, 2013, 1(26). 